\title{
How do invasive trees impact shrub layer diversity and productivity in temperate forests?
}

\author{
Marcin K. Dyderski ${ }^{1}$ (D) Andrzej M. Jagodziński ${ }^{1,2}$ (])
}

Received: 27 April 2020 / Accepted: 13 January 2021 / Published online: 24 February 2021

(c) The Author(s) 2021

\begin{abstract}
- Key message Invasive tree species alter taxonomic diversity and functioning of forest shrub layers: Prunus serotina increases shrub layer biomass two to three times but decreases its biodiversity, Robinia pseudoacacia slightly increases shrub layer biomass and has no effect on its biodiversity, while Quercus rubra both biomass and biodiversity of the shrub layer.

- Context Although the impact of invasive trees on understory biodiversity is known, very little data exist about their influence on shrub layer biodiversity and productivity.

- Aims To assess impacts of Prunus serotina Ehrh., Quercus rubra L., and Robinia pseudoacacia L. on shrub layer aboveground biomass, species composition, and alpha diversity.

- Methods We measured stand structures in a set of 168 study plots established in Wielkopolski National Park (W Poland), and we compared biomass and diversity metrics using generalized mixed-effects linear models.

- Results We found the lowest aboveground biomass of shrub layers in $Q$. rubra forests. P. sylvestris forests invaded by $P$. serotina had two to three times higher aboveground biomass than non-invaded forests. R. pseudoacacia forests had $27.8 \%$ higher shrub layer biomass than Quercus-Acer-Tilia forests. We found negative impacts of $Q$. rubra and negligible impacts of $R$. pseudoacacia on shrub layer alpha diversity metrics. However, the effect of $Q$. rubra was similar to native $F$. sylvatica. $P$. serotina negatively affected functional diversity, but its effects were lower in rich $P$. sylvestris forests than in poor $P$. sylvestris forests.

- Conclusion The introduction of alien tree species alters ecosystem services and species diversity of shrub layers. The direction and magnitude of these alterations are alien species-specific and context-dependent. Therefore, their management should account for their impacts.
\end{abstract}

Keywords Faith's phylogenetic diversity $\cdot$ Functional richness $\cdot$ Shannon's diversity $\cdot$ Non-metric multidimensional scaling $\cdot$ Stand-level biomass $\cdot$ Undergrowth

\section{Introduction}

Shrubs play an important role in forest ecosystems. Due to functional distinctiveness and ability to grow beneath forest canopies, shrubs utilize the available light between

Handling Editor: Laurent Bergès

Marcin K. Dyderski

mdyderski@man.poznan.pl

1 Institute of Dendrology, Polish Academy of Sciences, Parkowa 5, 62-035 Kornik, Poland

2 Faculty of Forestry and Wood Technology, Department of Game Management and Forest Protection, Poznań University of Life Sciences, Wojska Polskiego 71c, 60-625 Poznan, Poland understory and canopy layers. Numerous shrubs provide ecosystem services by increasing ecosystem biomass and soil erosion control. Most shrub species provide easilydecomposable litter, influencing nutrient cycling (e.g., Horodecki and Jagodziński 2017). Shrubs also provide food for both large (e.g., Bodziarczyk et al. 2017) and small herbivores (e.g., Karolewski et al. 2013, 2020).

Invasive tree species significantly alter ecosystem services (Castro-Díez et al. 2019) and biodiversity (Terwei et al. 2016; Šibíková et al. 2019). Such effects might be both positive, e.g., increase of carbon stock due to increased nitrogen availability (Rice et al. 2004), or negative, e.g., decreasing growth of native trees by the more effective acquisition of soil resources by invasive species (Hartman 
and McCarthy 2007). Moreover, invasive trees can affect biodiversity at various trophic levels (Hejda et al. 2017).

Although tree biomass pools in forest ecosystems are well-recognized, shrub biomass is rarely estimated (Woodbury et al. 2007). Despite the development of allometric models (Conti et al. 2019), forest inventories still provide only scarce information about shrub layer species composition and abundance. For that reason few studies estimated the biomass of shrub layers in forest complexes or at a national scale (Škèma et al. 2015). Lack of measurements has also prevented studies on impacts of invasive trees on shrub layers, with some exceptions (Slabejová et al. 2019; Mikulová et al. 2019). Therefore, we aimed to quantify the impact of three invasive woody species: Prunus serotina Ehrh., Quercus rubra L., and Robinia pseudoacacia L. on shrub layer biomass and functional, phylogenetic, and taxonomic diversity. We hypothesized that (1) the impact of $P$. serotina will differ from $Q$. rubra and $R$. pseudoacacia, as $P$. serotina occupies the shrub layer niche, in contrast to the canopy-dominants $Q$. rubra and $R$. pseudoacacia, and (2) the invasive species studied will decrease both biomass and taxonomic, phylogenetic, and functional alpha diversity of shrub layers.

\section{Material and methods}

\subsection{Study design}

We conducted our study in Wielkopolski National Park (WNP; W Poland; 52 $16^{\prime} \mathrm{N}, 16^{\circ} 48^{\prime} \mathrm{E}$ ), using a set of study plots designed to assess the spread of natural regeneration of the studied species, and described in detail in previous studies (Dyderski and Jagodziński 2019a). The climate in WNP is temperate, with a mean annual temperature of $8.4{ }^{\circ} \mathrm{C}$ and mean annual precipitation of $521 \mathrm{~mm}$, for the years 1951-2010. Forests of WNP were strongly transformed by former forest management, replacing mixed and broadleaved forests with monocultures of Scots pine. Before the establishment of the national park in 1957, numerous alien trees and shrubs had been introduced in WNP, resulting in the highest number of alien woody species among all national parks in Poland (Gazda and Szwagrzyk 2016). In WNP we arranged a set of 168 study plots with an area of 150-2000 $\mathrm{m}^{2}$ (mean $667 \pm 26 \mathrm{~m}^{2}$ ). The area of study plots was limited by canopy homogeneity - we aimed to cover the largest possible area within the stands studied, to stabilize the stand structure measurements. We distributed study plots across 21 blocks (Fig. 1), covering one or two pairs of $100 \mathrm{~m}^{2}$ formerly established square-plots for natural regeneration assessment (Dyderski and Jagodziński 2019a). Each block was established with a central plot within a monoculture of the invasive species studied (in the case of $P$. serotina-P. sylvestris monocultures with understories dominated by $P$. serotina). The plots used in this study covered two or four regeneration plots (pairs of square-plots), depending on the stand homogeneity: when two pairs were located in a homogenous stand, we established a single large plot, otherwise-two separate plots (Dyderski and Jagodziński 2019a). We excluded three study plots located in non-forest vegetation.

We divided study plots into nine categories (Table 1), according to tree stand species composition and soil fertility, as described in detail in previous studies (Dyderski and Jagodziński 2020b). The division follows the phytosociological variability of invaded and uninvaded vegetation: Fagus sylvatica-dominated forest refers to Deschampsio flexuosae-Fagetum, an acidophilous beech forest; Quercus petraea-dominated forest refers to Calamagrostio arundinaceae-Quercetum petraeae, an acidophilous oak forest; and QuercusAcer-Tilia forest refers to Galio sylvatici-Carpinetum, a fertile broadleaved forest. Pinus sylvestris-dominated forests represented two groups: poor (occupying mainly mesic sites of Leucobryo-Pinetum and Calamagrostio arundinaceae-Quercetum petraeae on podzols and brunic soils), and rich (on nutrient-rich luvisols and cambisols soils, which replaced Galio sylvatici-Carpinetum). In each of these two P. sylvestris groups we distinguished a variant invaded by $P$. serotina, which spontaneously colonized both types of forests. We assumed plots with more than 500 ind. ha ${ }^{-1}$ of $P$. serotina individuals as invaded.

\subsection{Data collection}

We recorded all trees and shrubs with heights above $1.3 \mathrm{~m}$ during August 2014 (9 blocks) and 2015 (12 blocks) within each stand structure plot (Fig. 1). We measured all living individuals with a diameter at breast height $(\mathrm{DBH}) \geq 5 \mathrm{~cm}$ including bark. For individuals with DBH $<5 \mathrm{~cm}$ we recorded the number of individuals. We identified all individuals at the species level in the field, following the Global Biodiversity Information Facility taxonomic backbone (GBIF 2019) for species nomenclature. For calculations of basal area $\left(\mathrm{m}^{2} \mathrm{ha}^{-1}\right)$ and biomass (see details below) we assumed the DBH of trees not measured to be $2.5 \mathrm{~cm}$, as this is the mid-point of the non-measured interval $(0-4.9 \mathrm{~cm})$. Despite decreasing calculation accuracy in comparison with overstory trees reaching large diameters, we considered such bias would have low significance for the total results. We assumed the shrub layer as trees and shrubs reaching up to $1 / 2$ of the height of the main canopy, classifying them in the 
Fig. 1 Scheme for a block of experimental plots in the field. Each of the 21 blocks covers a set of 18 square plots ( 100 $\mathrm{m}^{2}$ ), established for natural regeneration assessment (see Dyderski and Jagodziński 2018 for details), marked as grey squares. These plots were covered by stand structure plots (bold rectangles), established to cover homogenous forests. For that reason, a single study plot can cover two or four regeneration plots

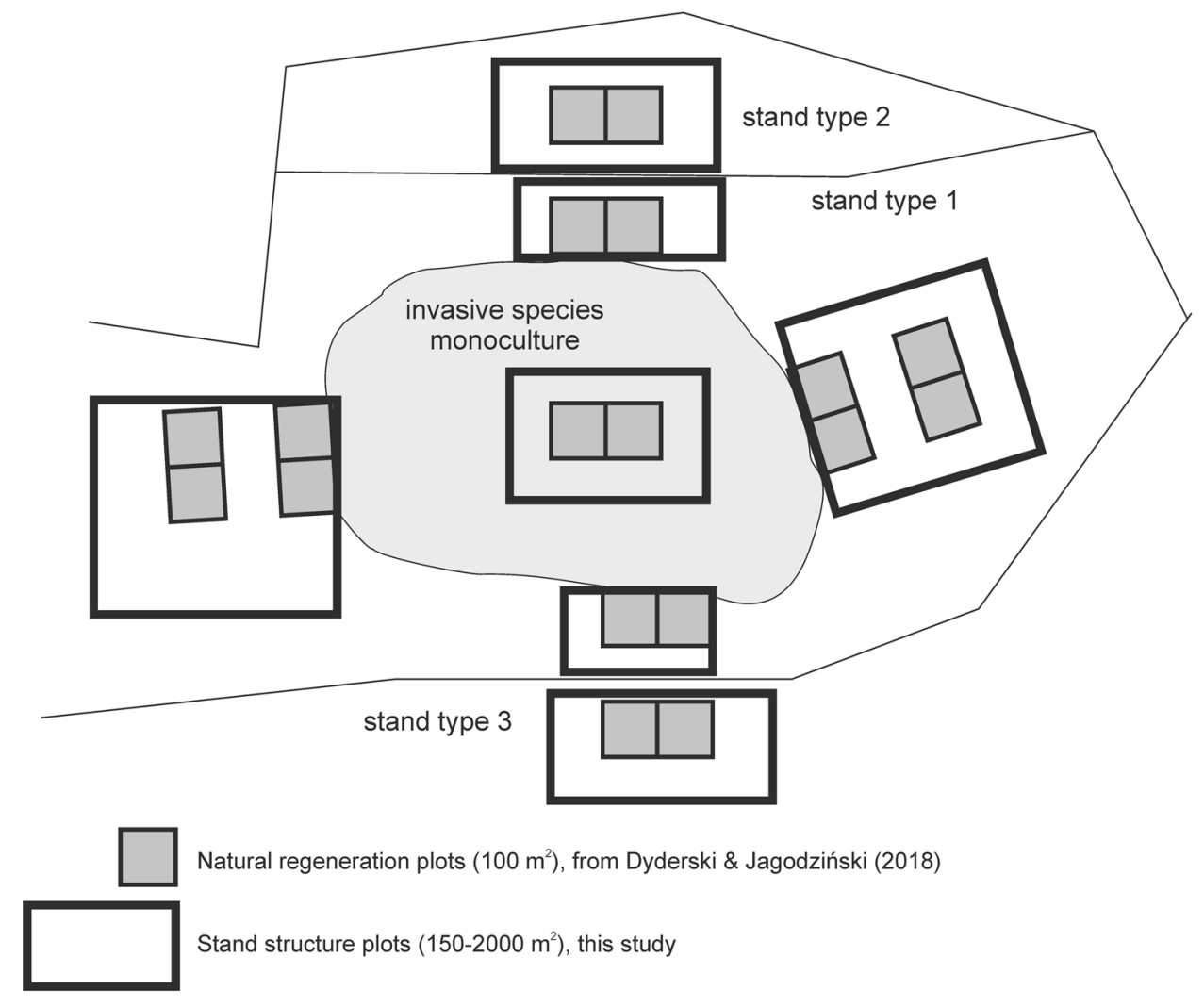

field, during measurements. We used that classification to account for functional differences between forest strata rather than applying a particular threshold of $\mathrm{DBH}$ or height. During measurements we measured the slope of the plot using a clinometer. We also used data about soil type and soil $\mathrm{C}: \mathrm{N}$ ratio from earlier studies (Dyderski and Jagodziński 2019b).

We calculated the aboveground biomass of each recorded individual using species- or genus-specific allometric models. When tree dimensions exceeded the maximum diameter of sample trees from the dataset used for a particular allometric model by $>20 \%$, or specific models for particular species were not available, we used the general model for broadleaved trees (Forrester et al. 2017). For some species not reaching DBH $>5 \mathrm{~cm}$ we used species-specific models based on root collar diameter, assuming root collar diameter to be $2.5 \mathrm{~cm}$. For details see the particular biomass models in the dataset (Dyderski and Jagodziński 2020a). We used the biomass of each species in each plot to calculate biomass proportions and for ordination analysis.

We analyzed three aspects of shrub layer alpha diversity-taxonomic, phylogenetic, and functional. We used species richness and Shannon's diversity index as metrics of taxonomic alpha diversity. We calculated them using the vegan package (Oksanen et al. 2018). To assess phylogenetic diversity we used a phylogenetic megatree included in the V.phylo.maker package (Jin and Qian 2019) to construct a tree of species occurring in shrub layers of study plots. We calculated Faith's phylogenetic diversity (i.e., sum of phylogenetic tree branch lengths, representing all species present in the community) and mean pairwise phylogenetic distance between species within the community, using the PhyloMeasures package (Tsirogiannis and Sandel 2016). We obtained functional traits from LEDA (Kleyer et al. 2008), BIEN (Enquist et al. 2016), BiolFlor (Klotz et al. 2002), and Pladias (Wild et al. 2019) databases: pollination mode, flowering start, and duration, specific leaf area, seed mass, height, and wood density. We obtained complete information about flowering, pollination, and seed mass traits, but SLA was available only for $88.9 \%$, height - for $98.1 \%$, and wood density-for $61.1 \%$ of species. We imputed missing data (see Pyšek et al. 2015 for rationale) using random forest imputation (Penone et al. 2014), implemented in the missForest package (Stekhoven and Bühlmann 2012). This method estimated missing values using known trait values and the first ten phylogenetic eigenvectors (Diniz-Filho et al. 1998), obtained using the PVR package (Santos 2018) and covering $71.7 \%$ of the variation in phylogenetic distances among 


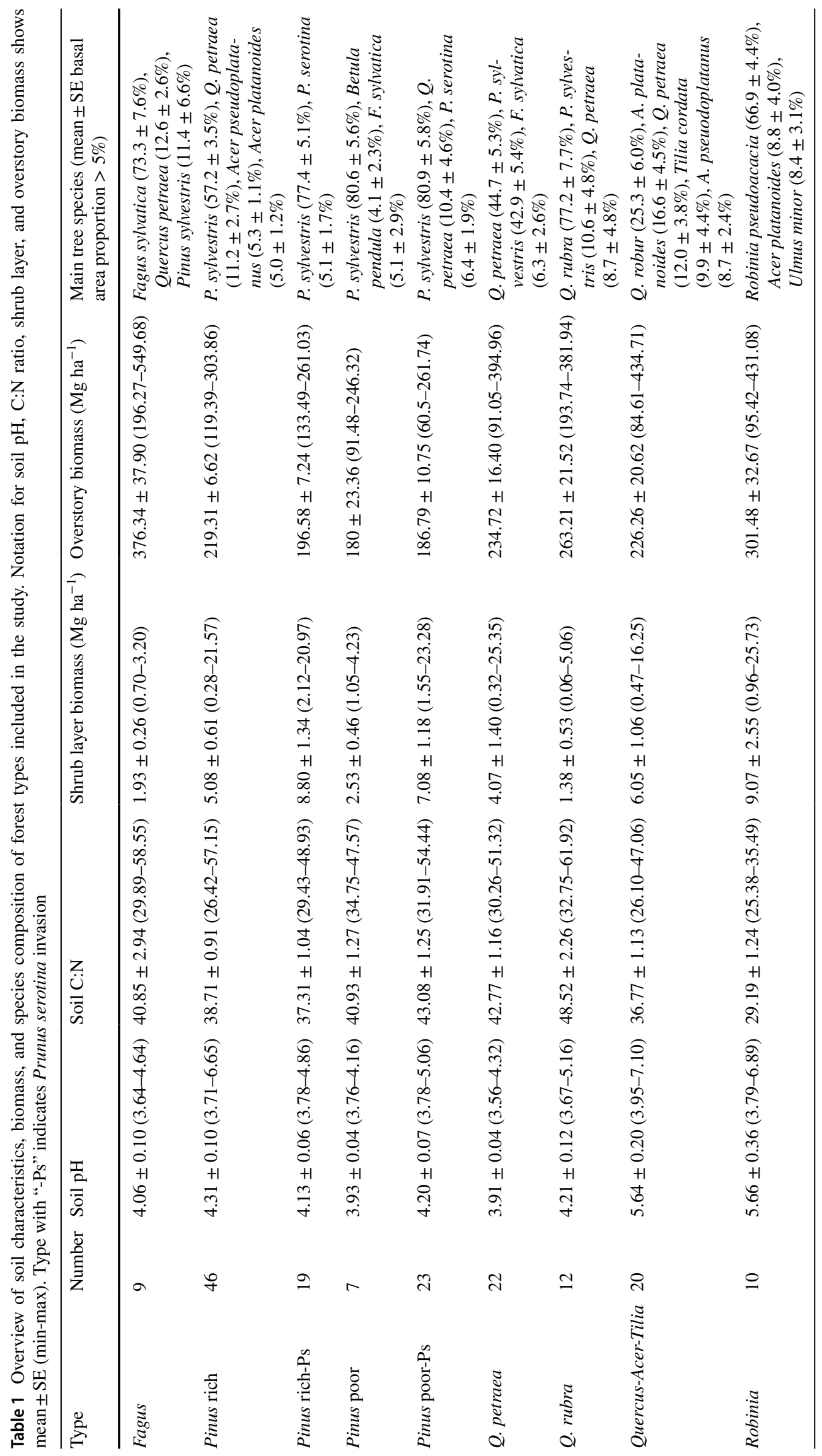


species. Normalized root-mean-squared error of imputed traits was 0.0314 . We calculated two indices of functional diversity: functional richness, expressing the quantity of plant functional types present in a community, and functional dispersion, expressing the size of the community species traits hypervolume within the functional trait space (Mason et al. 2005; Laliberté and Legendre 2010), using the $F D$ package (Laliberté et al. 2014).

\subsection{Data analysis}

We analyzed data using R software (v. 3.5.3; R Core Team 2019). We assessed the species composition of shrub layers within forest types using non-metric multidimensional scaling (NMDS), implemented in the vegan package (Oksanen et al. 2018). We used species biomass within study plots as an abundance metric and study plots as analytic units $(n=168)$. Species biomass was standardized using log-transformation, and NMDS was based on BrayCurtis distance matrix. We tested the significance of differences among forest types using adonis-permutationbased multivariate ANOVA, also accounting for a block design in permutations. We assessed differences among forest types studied using linear (LMMs) and generalized linear mixed-effects models (GLMMs), implemented in the lme4 package (Bates et al. 2015). We accounted for spatial dependence within blocks by including block ID as random intercepts in the models. In the initial models we included forest type, overstory aboveground biomass, stand age (data from management plans), slope, soil type, soil $\mathrm{C}: \mathrm{N}$ ratio, and soil $\mathrm{pH}$, and then we reduced models to decrease Akaike's Information Criterion, corrected for small sample size (AICc). We also reported $\mathrm{AICc}_{0}-\mathrm{AICc}$ of null models (intercept-only) and $\mathrm{AICc}_{\text {full }}-\mathrm{AICc}$ of the full model (including all variables) to show how final models were improved. After inspections of histograms and model QQ plots we used a log-normal distribution of shrub layer aboveground biomass, and normal distributions of other alpha diversity metrics. Due to the discrete character of species richness we assumed a Poisson distribution, after ensuring that the model was not overdispersed. We inspected residual distributions, impacts of outliers on results, and dispersion using diagnostic tests implemented in the DHARMa package (Hartig 2020). We also reported marginal $\left(R_{m}^{2}\right)$ and conditional $\left(R_{c}^{2}\right)$ coefficients of determination, expressing the proportion of variance explained by fixed effects only, and both fixed and random effects, respectively (Nakagawa and Schielzeth 2013), implemented in the MuMIn package (Barton 2017). In the case of functional richness we excluded plots where this parameter was unavailable due to low species richness (less than three species). To assess marginal effects of forest type (i.e.. assuming mean values of other predictors and excluding random effects), we calculated marginal means using the emmeans package (Lenth 2019) and we checked differences among variants using Tukey posteriori tests with multiple hypothesis testing adjustments. While interpreting the results, we followed the guidelines of
Fig. 2 Mean (+ SE) shrub layer aboveground biomass estimated using GLMM assuming log-normal distribution. Letters denote variants that are not different at $p=0.05$, according to Tukey posteriori test. For model details see Table 2

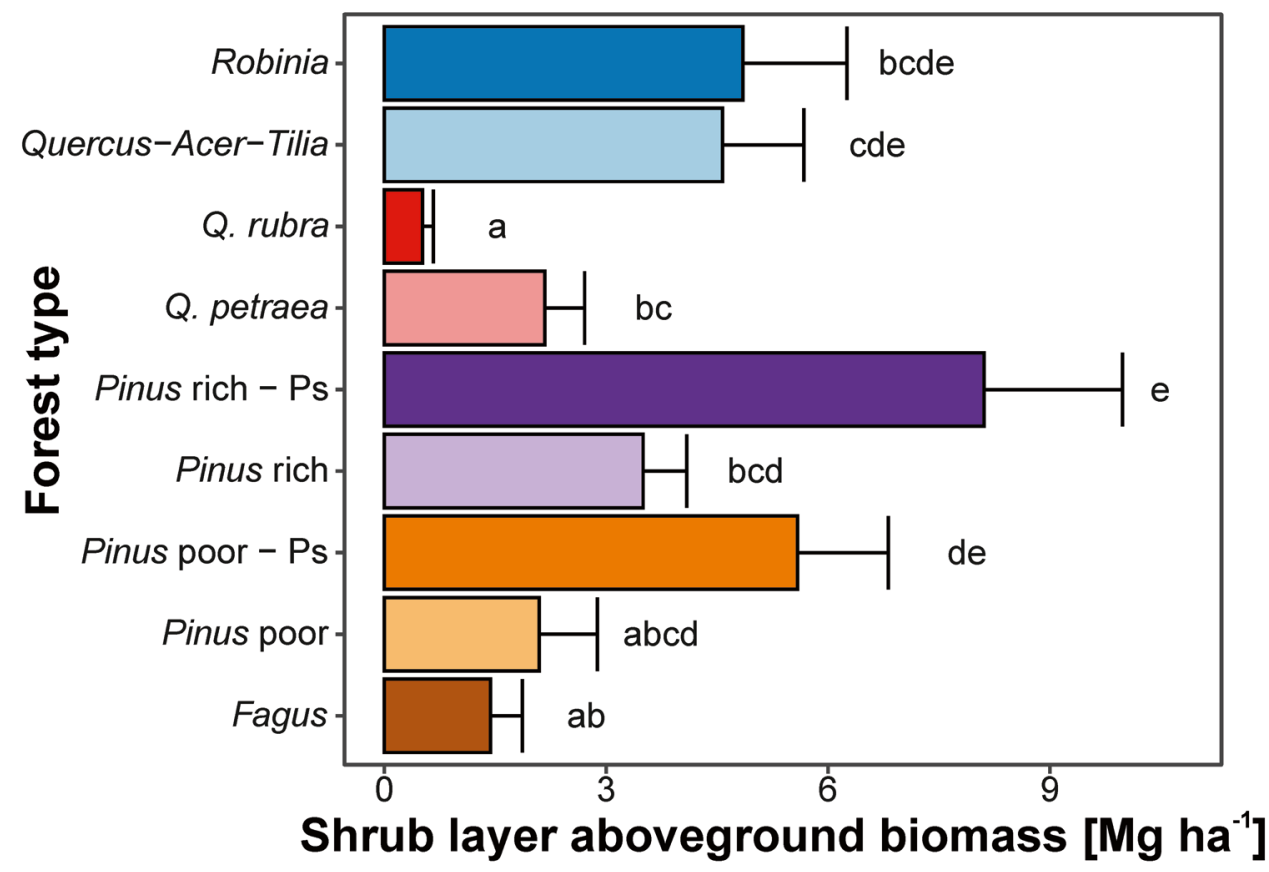


Fig. 3 Results of non-metric multidimensional scaling (NMDS) of shrub layer aboveground biomass proportions among species in each study plot $(n=168)$, colored by forest type. NMDS stress $=0.1638$. Labels represent species scores occurring in at least five study plots (alien species marked by red labels), abbreviated to the first three letters of each part of a binomial name (e.g., Fag. syl $=$ Fagus sylvatica)

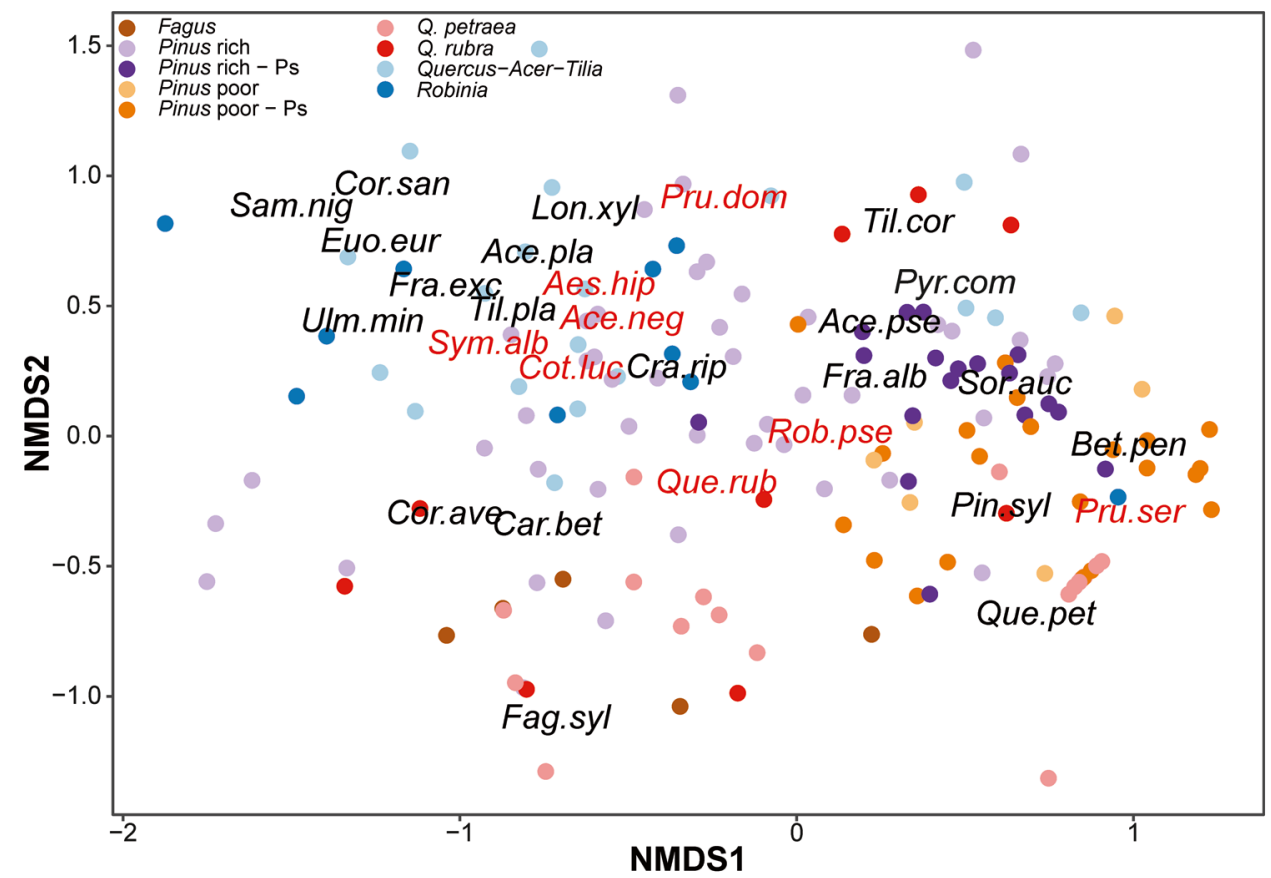

the American Statisticians Association (Wasserstein and Lazar 2016) and focused more on effect sizes than on p-values of pairwise comparisons. This allowed us to make conclusions based more on biological effects rather than on mere statistical measures undermined by small sample sizes.

\section{Results}

\subsection{Shrub layer aboveground biomass}

Despite testing stand age, slope, soil variables, and overstory aboveground biomass, the final model of aboveground biomass included only forest type $\left(\mathrm{AICc}=409.1, \mathrm{AICc}_{\text {full }}=489.1, \mathrm{AICc}_{0}=490.8\right.$, $R_{m}^{2}=0.337, R_{c}^{2}=0.529$; Table 2; Fig. 2). We found the lowest mean aboveground biomass of shrub layers in $Q$. rubra forests $\left(0.52 \pm 0.14 \mathrm{Mg} \mathrm{ha}^{-1}\right)$, which was about one-third of that in $F$. sylvatica forests $\left(1.43 \pm 0.43 \mathrm{Mg} \mathrm{ha}^{-1}\right)$ and one-fourth of that in $Q$. petraea forests $\left(2.17 \pm 0.54 \mathrm{Mg} \mathrm{ha}^{-1}\right)$. In both types of $P$. sylvestris forests we found approximately 2.5-times higher aboveground shrub biomass in $P$. serotina invaded than non-invaded forests $\left(8.11 \pm 1.87\right.$ vs. $3.50 \pm 0.59 \mathrm{Mg} \mathrm{ha}^{-1}$ in rich and $5.59 \pm 1.23$ vs $2.09 \pm 0.78 \mathrm{Mg} \mathrm{ha}^{-1}$ in poor $P$. sylvestris forests); however, these differences were statistically insignificant in a pairwise comparison. $R$. pseudoacacia and Quercus-Acer-Tilia forests $(4.85 \pm 1.41$ and $4.57 \pm 1.10 \mathrm{Mg} \mathrm{ha}^{-1}$, respectively) had higher shrub layer biomass than $Q$. rubra and $F$. sylvatica forests. Their shrub layer biomass was lower than invaded rich and poor $P$. sylvestris forests, but the differences were not statistically significant.

\subsection{Shrub layer species composition}

The shrub layers in forest types studied were dominated by the young regeneration of trees rather than shrub species (Table 3). Ordination (Fig. 3) revealed a gradient of species composition from fertile forest types on the left side of NMDS space (Robinia, Quercus-Acer-Tilia, and rich $P$. sylvestris forests) to nutrient-poor forest types on the right side (poor $P$. sylvestris and $Q$. petraea forests). Forest types differed significantly in species composition (ADONIS: d.f. $=8, F=10.01, p=0.001$ ) and explained $33.9 \%$ of the variation in species composition. Shrub layers dominated by shade-tolerant species, associated with high canopy cover, were grouped at the bottom of NDMS space. We also found that few species scores indicated their ecological optima in shrub layers outside forest types where they are dominants: R. pseudoacacia and Acer pseudoplatanus scores were shifted towards $P$. sylvestris forests (Fig. 4). Among invasive species studied $P$. serotina comprised a majority of biomass in most forest types. However, in noninvaded stands, its biomass was lower. We found only small proportions of $Q$. rubra in shrub layers in forest types other than those dominated by $Q$. rubra. 


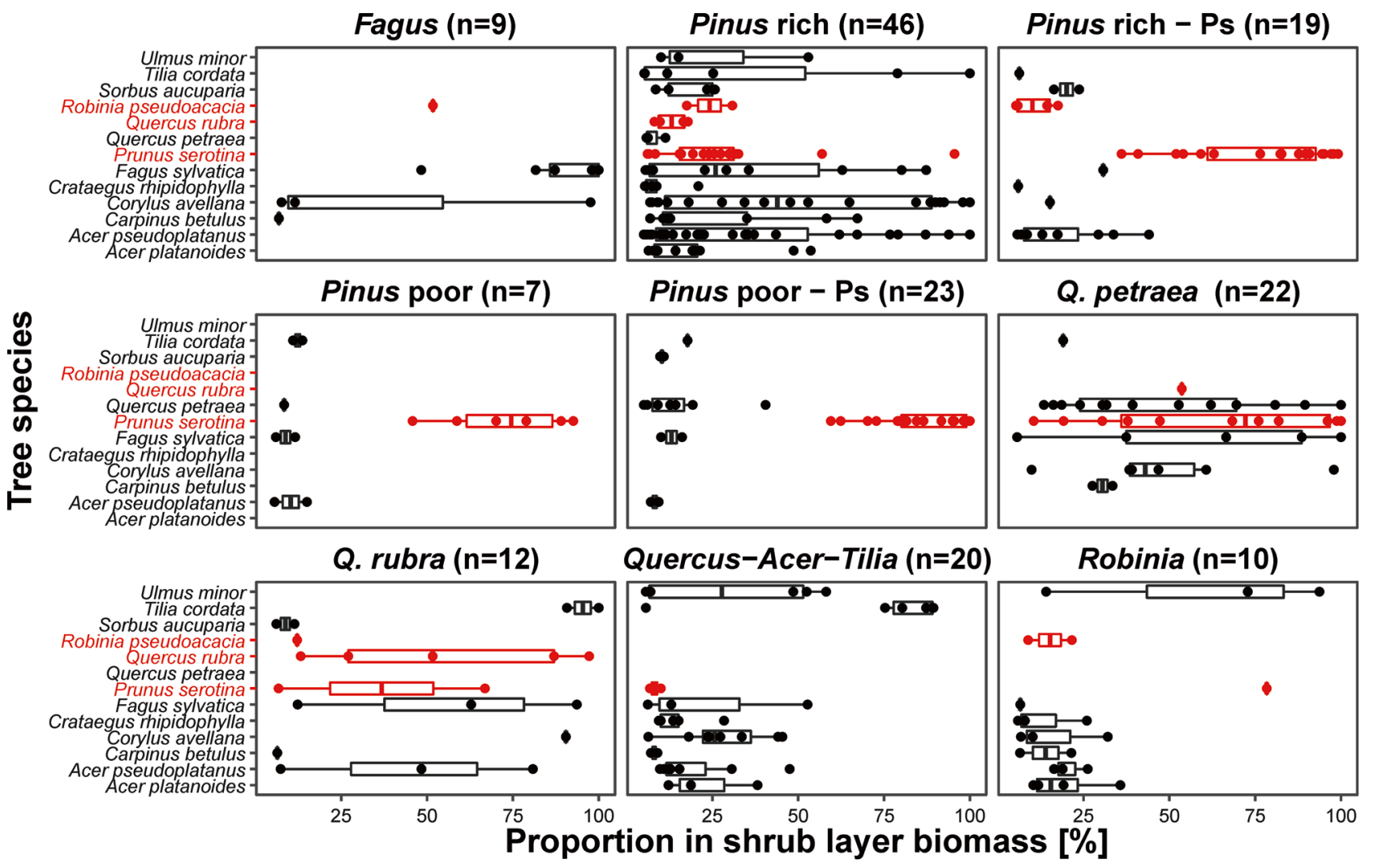

Fig. 4 The proportions of main species biomass in shrub layers among distinguished forest types. Boxplots indicate the first and third quartiles, the line inside each box indicates the median, and whiskers indicate the minimum and maximum without outstanding observa-

\subsection{Shrub layer alpha diversity}

We found differences in alpha diversity among forest types studied for all biodiversity indices except Shannon's diversity index and functional richness (Fig. 5; Table 4). All diversity metrics depended on the plot area; however, its effect size was low. Phylogenetic diversity indices were controlled by forest type functional richness depended on soil type and forest type. We found the lowest taxonomic diversity in $F$. sylvatica and $Q$. rubra forests, while the highest-in all $P$. sylvestris forest types, R. pseudoacacia, and Quercus-AcerTilia forests. We found the highest phylogenetic diversity and mean pairwise distance in non-invaded poor $P$. sylvestris forests, both types of rich P. sylvestris forest and QuercusAcer-Tilia forests, while the lowest-in $F$. sylvatica forests. We found the lowest functional richness in $Q$. rubra and $F$. sylvatica forests, and the highest-in Quercus-Acer-Tilia, $Q$. petraea, and non-invaded poor $P$. sylvestris forests. The functional richness of $Q$. petraea forests was twice that of $Q$. rubra forests. We found the lowest functional dispersion tions ( $>1.5$ interquartile range). Points represent particular observations. For clarity we drew only species occurring in at least 20 study plots and observations from plots with proportions $>5 \%$, sorted by overall proportion. Invasive species studied were marked by red color

in Fagus and invaded rich $P$. sylvestris forests, while the highest was in Quercus-Acer-Tilia forests.

\section{Discussion}

We found differences in shrub layer biomass among forest types studied. In most cases we found higher biomass than the averages from Lithuania fertile $\left(0.896 \pm 0.029 \mathrm{Mg} \mathrm{ha}^{-1}\right)$ and very fertile $\left(1.384 \pm 0.046 \mathrm{Mg} \mathrm{ha}^{-1}\right)$ sites (Škèma et al. 2015) and S Poland $\left(1.540 \pm 0.011 \mathrm{Mg} \mathrm{ha}^{-1}\right.$; Orzeł 2015). Our results are in line with findings from Lithuania where more fertile forest types had higher shrub biomass (Škèma et al. 2015). This contradicts the findings of Orzeł (2015), who found higher shrub layer biomass in the less fertile forest types.

Our study revealed that $P$. serotina and $R$. pseudoacacia invaded forests had higher shrub layer biomass than native forest types, except $Q$. petraea and $F$. sylvatica forests. 


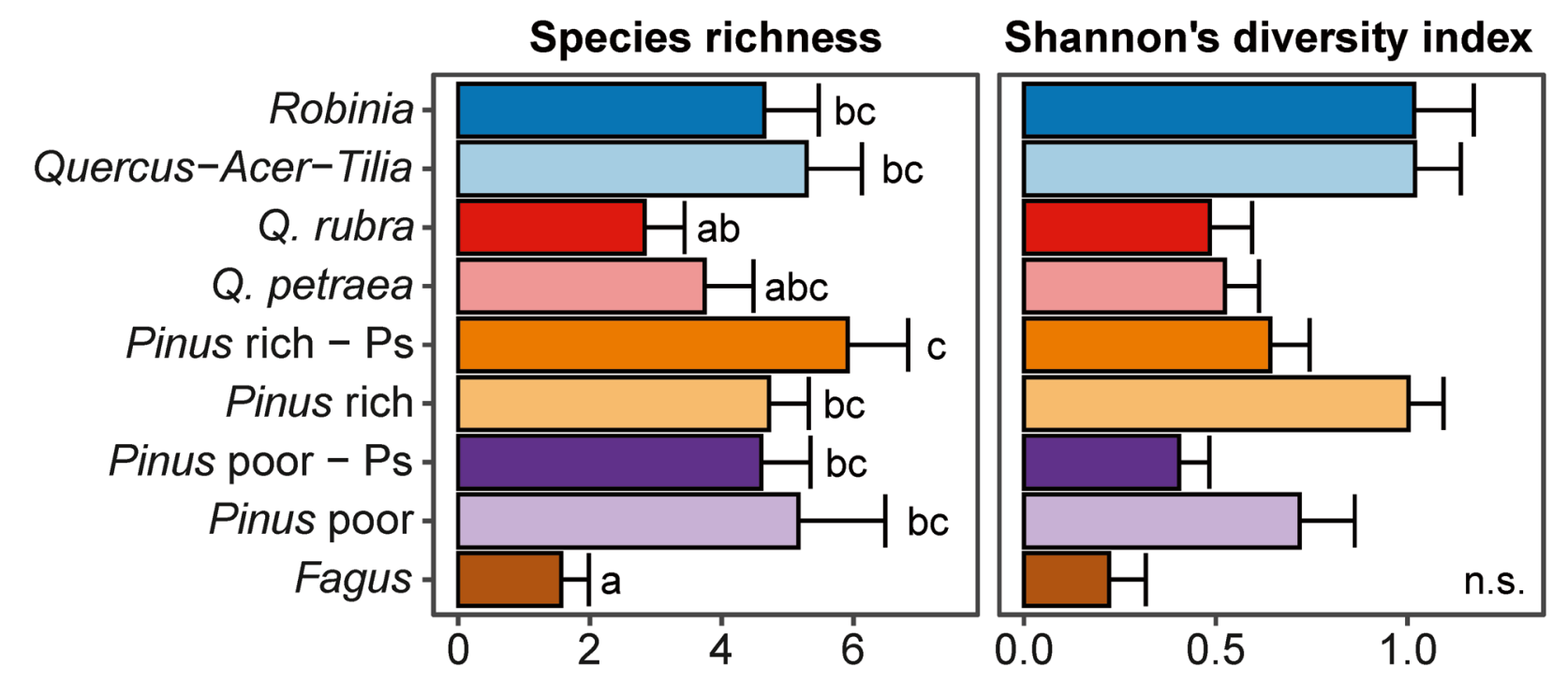

Faith's phylogenetic diversity Mean pairwise distance
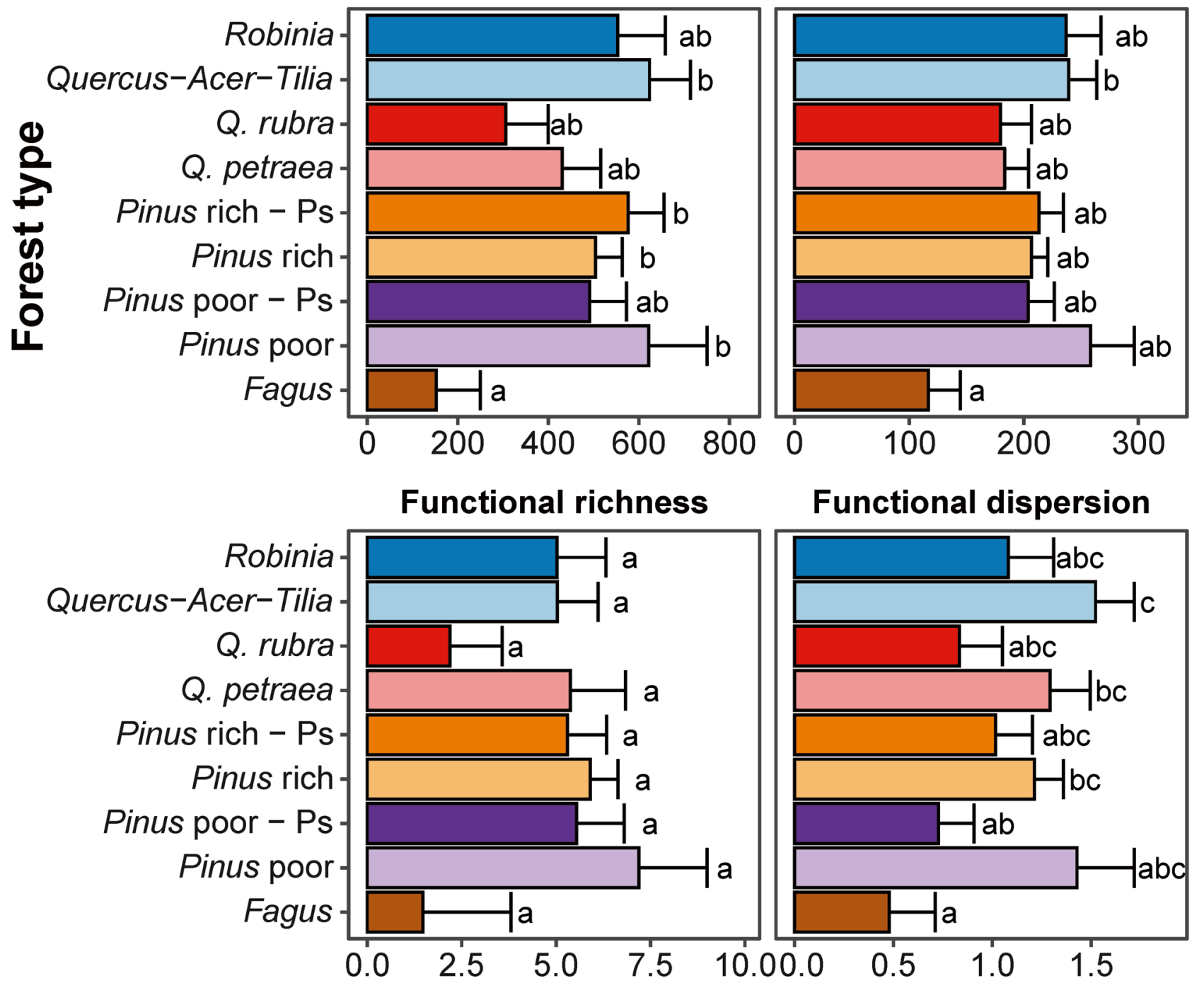

Fig. 5 Mean (+ SE) values of shrub layer alpha biodiversity indices estimated using GLMMs. Letters denote variants which are not different at $p=0.05$, according to Tukey posteriori test, n.s. the final model did not reveal an impact of forest type. For model details see Table 4 
The latter types are known for either low soil fertility, unfavorable for numerous shrub species (Dyderski and Jagodziński 2020b), or limited light availability, similarly to Q. rubra (Jagodziński et al. 2018). Negative impacts of Q. rubra might be compared with other tree species with a high leaf area. For example, a removal experiment in Picea abies monocultures revealed that removing 50\% of tree basal area resulted in twice higher shrub species richness (Heinrichs and Schmidt 2009). Also, alien Pinus nigra, transmitting more light beneath the canopy layer than native species, had twice the shrub layer cover (Mikulová et al. 2019).

This is in line with the findings of Ostrom (1983), who found almost 2.5-fold higher shrub biomass in lighttransmitting Larix laricina forests than shade-casting Thuja occidentalis forests. The negative impacts of $Q$. rubra on both shrub layer biodiversity and biomass is in line with studies concerning herb layer biodiversity (Marozas et al. 2009; Chmura 2013; Dyderski and Jagodziński 2020b) and dominant species biomass (Woziwoda et al. 2019). Similarly, the mechanism of increased light availability might be connected with the positive impacts of $R$. pseudoacacia on shrub layer biomass. Moreover, due to the ability to absorb nitrogen from the atmosphere (Rice et al. 2004), R. pseudoacacia forests allow for higher growth rates of understory plants, both woody and non-woody. This can be also indicated by high overstory biomass in $R$. pseudoacacia forest (Table 1). Therefore, previous studies reported positive (e.g., Gentili et al. 2019), negative (e.g., Slabejová et al. 2019), or no effects (e.g., Hejda et al. 2017) of $R$. pseudoacacia on understory vegetation.

The main differences among invasive species studied are connected with their life forms-P. serotina usually dominates shrub layers, contributing to higher shrub layer biomass. It is connected with the ability for fast height increments after release from growth suppression (Closset-Kopp et al. 2007), allowing it to increase biomass up to 24,000 times in eight years (Jagodziński et al. 2019). Although $R$. pseudoacacia is also able to dominate the shrub layer (Slabejová et al. 2019), we did not find such an effect, due to limitations on the survival of natural regeneration (Dyderski and Jagodziński $2019 \mathrm{~b}$ ). We found lower effects of $P$. serotina on shrub layer biomass in rich $P$. sylvestris forests than in poor $P$. sylvestris forests. This may be connected with higher soil fertility, hosting more native species of shrubs, mainly typical of broadleaved forests (Zerbe and Wirth 2006). $P$. serotina successfully colonized both habitat types and outcompeted native species. Different impacts of invasive species in low and high soil fertility are widely known in invasion ecology as context-dependence (Sapsford et al. 2020). This highlights the need to account for habitat-specificity in management plans for invasive trees.

\section{Conclusion}

Our study demonstrated how invasive tree species influenced productivity and biodiversity in temperate forests. Depending on forest management and conservation aims, removal of invasive trees might lead to decreasing ecosystem biomass pools but allow for regeneration of native biodiversity. However, impacts are species- and context-dependent, therefore decisionmaking about the introduction or eradication of invasive tree species requires accounting for a wide range of impact assessments. Moreover, we also provided new data about the primary production and carbon sequestration of the shrub layer.

\section{Disclaimer}

The funders had no role in the design of the study; in the collection, analyses, or interpretation of data; in the writing of the manuscript; or in the decision to publish the results.

\section{Appendix}

Table 2 Impacts of forest type on shrub layer aboveground biomass, estimated using LMM assuming log-normal distribution. $\mathrm{AICc}=409.1, \mathrm{AICc}_{\text {full }}=489.1, \mathrm{AICc}_{0}=490.8$. Significant variables were italicized

\begin{tabular}{lrlrr}
\hline Variable & Estimate & SE & \multicolumn{1}{l}{$t$ value } & $\operatorname{Pr}(>|t|)$ \\
\hline (Intercept) & 7.2691 & 0.2990 & 24.3090 & $<0.0001$ \\
type = Pinus rich & 0.8913 & 0.3023 & 2.9490 & 0.0037 \\
type = Pinus rich-Ps & 1.7319 & 0.3534 & 4.9010 & 0.0000 \\
type = Pinus poor & 0.3780 & 0.4630 & 0.8160 & 0.4155 \\
type = Pinus poor-Ps & 1.3588 & 0.3473 & 3.9130 & 0.0001 \\
type =Q. petraea & 0.4136 & 0.3425 & 1.2080 & 0.2291 \\
type $=$ Q. rubra & -1.0216 & 0.3730 & -2.7390 & 0.0069 \\
type = Quercus-Acer-Tilia & 1.1584 & 0.3563 & 3.2510 & 0.0014 \\
type = Robinia & 1.2176 & 0.3922 & 3.1050 & 0.0023 \\
Random effects SD: & Block & 0.497 & Residuals & 0.778 \\
\hline
\end{tabular}




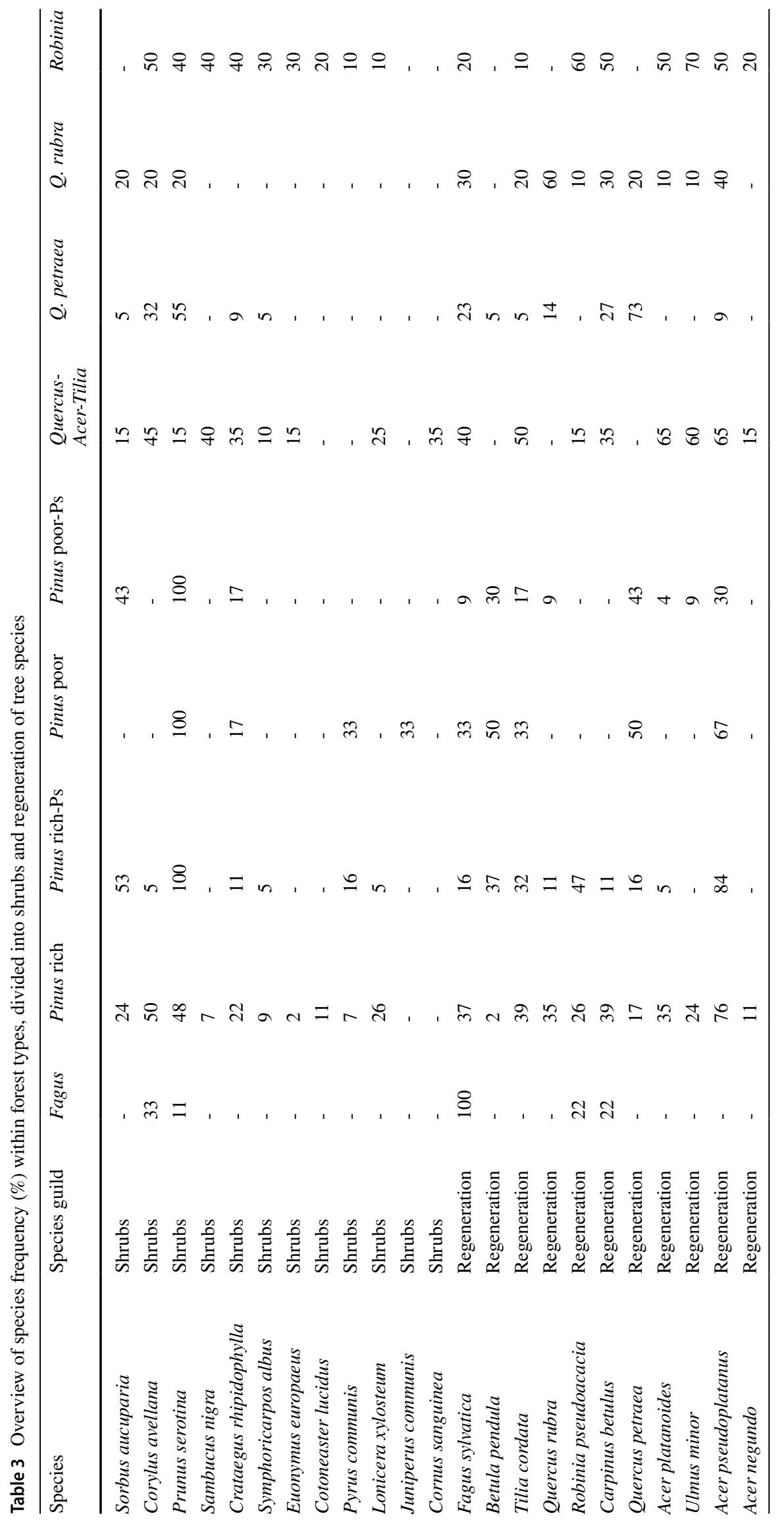


Table 4 Models of shrub layer alpha diversity, estimated using Gaussian distribution GLMMs (for species richness - Poisson distribution and $\mathrm{z}$ statistic instead of $\mathrm{t}$ ). Significant variables were bolded. $\mathrm{AICc}$ - Akaike Information Criterion, $\mathrm{AICc}_{0}-\mathrm{AIC}$ of null model (intercept-only), $\mathrm{AICc}_{\text {full }}-\mathrm{AIC}$ of full model (including all hypoth- esized variables), $\mathrm{R}_{\mathrm{m}}^{2}$ - marginal coefficient of determination, $\mathrm{R}_{\mathrm{C}}^{2}$ - conditional coefficient of determination; *for Shannon's index model block random effect $\mathrm{SD}=0.43, \mathrm{AICc}=198.4, \mathrm{AICc}_{\text {full }}=275.0$, $\mathrm{AICc}_{0}=199.5, \mathrm{R}_{\mathrm{m}}^{2}=0.005, \mathrm{R}_{\mathrm{c}}^{2}=0.577$

\begin{tabular}{|c|c|c|c|c|c|}
\hline Response & Variable & Estimate & SE & t value & $\operatorname{Pr}(>|t|)$ \\
\hline Species richness & (Intercept) & 0.2992 & 0.2806 & 1.0660 & 0.2863 \\
\hline Block SD $=0.464$ & type $=$ Pinus poor & 1.1945 & 0.3506 & 3.4070 & 0.0007 \\
\hline $\mathrm{R}_{\mathrm{m}}^{2}=0.185$ & type $=$ Pinus poor $-\mathrm{Ps}$ & 1.0788 & 0.2885 & 3.7390 & 0.0002 \\
\hline $\mathrm{R}_{\mathrm{c}}^{2}=0.611$ & type $=$ Pinus rich & 1.1043 & 0.2562 & 4.3110 & $<0.0001$ \\
\hline $\mathrm{AICc}=735.0$ & type $=$ Pinus rich $-\mathrm{Ps}$ & 1.3298 & 0.2789 & 4.7690 & $<0.0001$ \\
\hline $\mathrm{AICc}_{\text {full }}=749.7$ & type $=Q \cdot$ petraea & 0.8720 & 0.3016 & 2.8910 & 0.0038 \\
\hline \multirow[t]{4}{*}{$\mathrm{AICc}_{0}=757.4$} & type $=Q . r u b r a$ & 0.5930 & 0.3084 & 1.9230 & 0.0545 \\
\hline & type $=$ Quercus-Acer-Tilia & 1.2184 & 0.2769 & 4.3990 & $<0.0001$ \\
\hline & type $=$ Robinia & 1.0889 & 0.2878 & 3.7830 & 0.0002 \\
\hline & plot area & 2.2364 & 1.1208 & 1.9950 & 0.0460 \\
\hline \multirow[t]{2}{*}{ Shannon's index* } & (Intercept) & 0.6744 & 0.1174 & 5.7430 & $<0.0001$ \\
\hline & plot area & 1.1690 & 0.9572 & 1.2210 & 0.2240 \\
\hline Faith's phylogenetic diversity & (Intercept) & -110.5760 & 314.8080 & -0.3510 & 0.7259 \\
\hline Block $\mathrm{SD}=161.4$ & type $=$ Pinus poor & 469.2930 & 146.7530 & 3.1980 & 0.0017 \\
\hline $\mathrm{R}_{\mathrm{m}}^{2}=0.200$ & type $=$ Pinus poor $-\mathrm{Ps}$ & 338.9640 & 108.1080 & 3.1350 & 0.0021 \\
\hline $\mathrm{R}_{\mathrm{c}}^{2}=0.458$ & type $=$ Pinus rich & 352.0510 & 92.8780 & 3.7900 & 0.0002 \\
\hline $\mathrm{AICc}=2134.2$ & type $=$ Pinus rich $-\mathrm{Ps}$ & 423.9690 & 110.8620 & 3.8240 & 0.0002 \\
\hline $\mathrm{AICc}_{\text {full }}=2135.1$ & type $=Q \cdot$ petraea & 278.2840 & 104.7440 & 2.6570 & 0.0088 \\
\hline \multirow[t]{13}{*}{$\mathrm{AICc}_{0}=2317.8$} & type $=Q . r u b r a$ & 153.7750 & 113.7170 & 1.3520 & 0.1786 \\
\hline & type $=$ Quercus-Acer-Tilia & 471.3920 & 121.1010 & 3.8930 & 0.0002 \\
\hline & type $=$ Robinia & 400.9820 & 133.4240 & 3.0050 & 0.0031 \\
\hline & plot area & 1317.3750 & 653.2330 & 2.0170 & 0.0456 \\
\hline & soil $=$ Cambic Brunic Arenosols & -57.7010 & 99.0880 & -0.5820 & 0.5615 \\
\hline & soil $=$ Cambisols & 311.7780 & 153.8550 & 2.0260 & 0.0513 \\
\hline & soil = Fluvic cambisols & 17.1870 & 121.5210 & 0.1410 & 0.8877 \\
\hline & soil=Haplic_luvisols & 16.2190 & 77.1860 & 0.2100 & 0.8339 \\
\hline & soil $=$ Luvisols & -9.9400 & 156.6710 & -0.0630 & 0.9495 \\
\hline & soil $=$ Phaeozems & 7.1050 & 174.6060 & 0.0410 & 0.9676 \\
\hline & soil pH & 16.5210 & 51.5050 & 0.3210 & 0.7489 \\
\hline & soil C:N ratio & 1.1630 & 6.2510 & 0.1860 & 0.8526 \\
\hline & slope & 5.0060 & 4.0180 & 1.2460 & 0.2149 \\
\hline Mean pairwise distance & (Intercept) & 72.4005 & 90.1711 & 0.8030 & 0.4236 \\
\hline Block SD $=173.8$ & type $=$ Pinus poor & 141.5714 & 44.7482 & 3.1640 & 0.0019 \\
\hline $\mathrm{R}_{\mathrm{m}}^{2}=0.156$ & type $=$ Pinus poor $-\mathrm{Ps}$ & 87.0001 & 33.2801 & 2.6140 & 0.0099 \\
\hline $\mathrm{R}_{\mathrm{c}}^{2}=0.163$ & type $=$ Pinus rich & 90.0641 & 28.8302 & 3.1240 & 0.0022 \\
\hline $\mathrm{AICc}=1786.9$ & type $=$ Pinus rich $-\mathrm{Ps}$ & 96.5288 & 33.6354 & 2.8700 & 0.0047 \\
\hline $\mathrm{AICc}_{\text {full }}=1791.2$ & type $=Q \cdot$ petraea & 66.5041 & 31.7062 & 2.0980 & 0.0378 \\
\hline \multirow[t]{9}{*}{$\mathrm{AICc}_{0}=1913.2$} & type $=Q . r u b r a$ & 62.8079 & 35.9769 & 1.7460 & 0.0830 \\
\hline & type $=$ Quercus-Acer-Tilia & 122.4130 & 37.1091 & 3.2990 & 0.0012 \\
\hline & type $=$ Robinia & 120.1737 & 40.9860 & 2.9320 & 0.0039 \\
\hline & plot area & 87.6556 & 196.8772 & 0.4450 & 0.6569 \\
\hline & soil $=$ Cambic Brunic Arenosols & -21.9510 & 25.6269 & -0.8570 & 0.3953 \\
\hline & soil $=$ Cambisols & 4.3161 & 30.5268 & 0.1410 & 0.8890 \\
\hline & soil $=$ Fluvic cambisols & -20.8138 & 34.5952 & -0.6020 & 0.5487 \\
\hline & soil=Haplic_luvisols & -18.3451 & 20.1093 & -0.9120 & 0.3653 \\
\hline & soil $=$ Luvisols & 37.9113 & 42.9147 & 0.8830 & 0.3802 \\
\hline
\end{tabular}


Table 4 (continued)

\begin{tabular}{|c|c|c|c|c|c|}
\hline Response & Variable & Estimate & SE & $\mathrm{t}$ value & $\operatorname{Pr}(>|\mathrm{t}|)$ \\
\hline & soil = Phaeozems & -12.8832 & 44.5796 & -0.2890 & 0.7735 \\
\hline & soil pH & -0.1346 & 14.1209 & -0.0100 & 0.9924 \\
\hline & soil C:N ratio & 1.5462 & 1.8371 & 0.8420 & 0.4016 \\
\hline & slope & 1.0309 & 1.2053 & 0.8550 & 0.3939 \\
\hline Functional richness & (Intercept) & -3.0597 & 2.5481 & -1.2010 & 0.2327 \\
\hline Block SD $=1.654$ & type $=$ Pinus poor & 5.7151 & 2.8663 & 1.9940 & 0.0490 \\
\hline $\mathrm{R}_{\mathrm{m}}^{2}=0.306$ & type $=$ Pinus poor $-\mathrm{Ps}$ & 4.0715 & 2.5775 & 1.5800 & 0.1175 \\
\hline $\mathrm{R}_{\mathrm{c}}^{2}=0.471$ & type $=$ Pinus rich & 4.4319 & 2.2961 & 1.9300 & 0.0566 \\
\hline $\mathrm{AICc}=592.2$ & type $=$ Pinus rich $-\mathrm{Ps}$ & 3.8239 & 2.4957 & 1.5320 & 0.1288 \\
\hline $\mathrm{AICc}_{\mathrm{full}}=625.8$ & type $=Q$. petraea & 3.9039 & 2.4783 & 1.5750 & 0.1186 \\
\hline \multirow[t]{11}{*}{$\mathrm{AICc}_{0}=633.7$} & type $=Q . r u b r a$ & 0.7129 & 2.5616 & 0.2780 & 0.7814 \\
\hline & type $=$ Quercus-Acer-Tilia & 3.5561 & 2.4585 & 1.4460 & 0.1512 \\
\hline & type $=$ Robinia & 3.5517 & 2.5750 & 1.3790 & 0.1709 \\
\hline & plot area & 29.7410 & 9.9720 & 2.9820 & 0.0036 \\
\hline & soil $=$ Cambic Brunic Arenosols & 1.3442 & 1.4428 & 0.9320 & 0.3545 \\
\hline & soil $=$ Cambisols & 4.8713 & 1.8885 & 2.5790 & 0.0181 \\
\hline & soil $=$ Fluvic cambisols & 4.7057 & 1.5907 & 2.9580 & 0.0040 \\
\hline & soil=Haplic_luvisols & 3.1945 & 1.2380 & 2.5800 & 0.0126 \\
\hline & soil $=$ Luvisols & 1.1916 & 2.1302 & 0.5590 & 0.5772 \\
\hline & soil = Phaeozems & 2.7698 & 1.8606 & 1.4890 & 0.1422 \\
\hline & soil pH & -0.1346 & 14.1209 & -0.0100 & 0.9924 \\
\hline Functional dispersion & (Intercept) & 0.4997 & 0.2537 & 1.9700 & 0.0509 \\
\hline Block SD $=0.504$ & type $=$ Pinus poor & 0.9499 & 0.3459 & 2.7460 & 0.0068 \\
\hline $\mathrm{R}_{\mathrm{m}}^{2}=0.122$ & type $=$ Pinus poor $-\mathrm{Ps}$ & 0.2492 & 0.2577 & 0.9670 & 0.3350 \\
\hline $\mathrm{R}_{\mathrm{c}}^{2}=0.513$ & type $=$ Pinus rich & 0.7353 & 0.2215 & 3.3190 & 0.0011 \\
\hline $\mathrm{AICc}=347.8$ & type $=$ Pinus rich $-\mathrm{Ps}$ & 0.5377 & 0.2616 & 2.0550 & 0.0416 \\
\hline $\mathrm{AICc}_{\text {full }}=408.9$ & type $=Q$. petraea & 0.8143 & 0.2533 & 3.2150 & 0.0016 \\
\hline \multirow[t]{4}{*}{$\mathrm{AICc}_{0}=349.7$} & type $=Q . r u b r a$ & 0.3549 & 0.2721 & 1.3040 & 0.1944 \\
\hline & type $=$ Quercus-Acer-Tilia & 1.0440 & 0.2654 & 3.9330 & 0.0001 \\
\hline & type $=$ Robinia & 0.6024 & 0.2921 & 2.0630 & 0.0409 \\
\hline & plot area & -0.3263 & 1.5009 & -0.2170 & 0.8282 \\
\hline
\end{tabular}

Supplementary information The online version contains supplementary material available at https://doi.org/10.1007/s13595-021-01033-8.

Acknowledgments We are thankful to Dr. Laurent Bergès and two anonymous Reviewers for valuable comments to the earlier draft of the manuscript.

Authors' contributions Conceptualization: MKD and AMJ; Methodology: MKD and AMJ; Formal Analysis: MKD; Investigation: MKD; Data curation: MKD; Writing — original draft: MKD; Writing—review and editing: MKD and AMJ; Visualization: MKD; Supervision: AMJ; Funding acquisition: MKD and AMJ.

Funding The study was financed by National Science Centre, Poland, under the project no. 2015/19/N/NZ8/03822 entitled: "Ecophysiological and ecological determinants of invasiveness of trees and shrubs with the examples of Padus serotina, Quercus rubra and Robinia pseudoacacia." The study was partially supported by the Institute of Dendrology, Polish Academy of Sciences.
Data availability The datasets generated during and/or analyzed during the current study are available in the figshare repository, https://doi. org/10.6084/m9.figshare. 13026641

\section{Declarations}

Conflicts of interest The authors declare that they have no conflict of interest.

Ethics approval The study was conducted in Wielkopolski National Park under permission nos. 25/2014, 7/2105, 7A/2015, 6/2016, 3/2017, and $3 / 2018$.

Open Access This article is licensed under a Creative Commons Attribution 4.0 International License, which permits use, sharing, adaptation, distribution and reproduction in any medium or format, as long as you give appropriate credit to the original author(s) and the source, provide a link to the Creative Commons licence, and indicate if changes were made. The images or other third party material in this article are 
included in the article's Creative Commons licence, unless indicated otherwise in a credit line to the material. If material is not included in the article's Creative Commons licence and your intended use is not permitted by statutory regulation or exceeds the permitted use, you will need to obtain permission directly from the copyright holder. To view a copy of this licence, visit http://creativecommons.org/licenses/by/4.0/.

\section{References}

Bartoń K (2017) MuMIn: Multi-Model Inference. https://cran.r-project. org $/$ package $=$ MuMIn

Bates D, Mächler M, Bolker B, Walker S (2015) Fitting linear mixedeffects models using lme4. J Stat Softw 67:1-48. https://doi. org/10.18637/jss.v067.i01

Bodziarczyk J, Zwijacz-Kozica T, Gazda A, Szewczyk J, Frączek M, Zięba A, Szwagrzyk J et al (2017) Species composition, elevation, and former management type affect browsing pressure on forest regeneration in the Tatra National Park. For Res Pap 78:238-247. https://doi.org/10.1515/frp-2017-0026

Castro-Díez P, Vaz AS, Silva JS, van Loo M, Alonso Á, Aponte C, Bayón Á, Bellingham PJ, Chiuffo MC, DiManno N, Julian K, Kandert S, Porta NL, Marchante H, Maule HG, Mayfield MM, Metcalfe D, Monteverdi MC, Núñez MA, Ostertag R, Parker IM, Peltzer DA, Potgieter LJ, Raymundo M, Rayome D, ReismanBerman O, Richardson DM, Roos RE, Saldaña A, Shackleton RT, Torres A, Trudgen M, Urban J, Vicente JR, Vilà M, Ylioja T, Zenni RD, Godoy O et al (2019) Global effects of non-native tree species on multiple ecosystem services. Biol Rev 94:1477-1501. https://doi.org/10.1111/brv.12511

Chmura D (2013) Impact of alien tree species Quercus rubra L. on understorey environment and flora: a study of the Silesian Upland (southern Poland). Pol J Ecol 61:431-442

Closset-Kopp D, Chabrerie O, Valentin B, Delachapelle H, Decocq G (2007) When Oskar meets Alice: does a lack of trade-off in r/Kstrategies make Prunus serotina a successful invader of European forests? For Ecol Manage 247:120-130. https://doi.org/10.1016/j. foreco.2007.04.023

Conti G, Gorné LD, Zeballos SR, Lipoma ML, Gatica G, Kowaljow E, Whitworth-Hulse JI, Cuchietti A, Poca M, Pestoni S, Fernandes PM et al (2019) Developing allometric models to predict the individual aboveground biomass of shrubs worldwide. Glob Ecol Biogeogr 28:961-975. https://doi.org/10.1111/geb.12907

Diniz-Filho JAF, de Sant'Ana CER, Bini LM, (1998) An eigenvector method for estimating phylogenetic inertia. Evol 52:1247-1262. https://doi.org/10.1111/j.1558-5646.1998.tb02006.x

Dyderski MK, Jagodziński A (2020a) Shrub layer diversity and productivity in temperate forests dataset. Figshare Repository V1. https://doi.org/10.6084/m9.figshare.13026641

Dyderski MK, Jagodziński AM (2019a) Similar impacts of alien and native tree species on understory light availability in a temperate forest. For 10:951. https://doi.org/10.3390/f10110951

Dyderski MK, Jagodziński AM (2020b) Impact of invasive tree species on natural regeneration species composition, diversity, and density. For 11:456. https://doi.org/10.3390/f11040456

Dyderski MK, Jagodziński AM (2019b) Seedling survival of Prunus serotina Ehrh., Quercus rubra L. and Robinia pseudoacacia L. in temperate forests of Western Poland. For Ecol Manage 450:117498. https://doi.org/10.1016/j.foreco.2019.117498

Dyderski MK, Jagodziński AM (2018) Drivers of invasive tree and shrub natural regeneration in temperate forests. Biol Invasions 20:2363-2379. https://doi.org/10.1007/s10530-018-1706-3

Enquist BJ, Condit R, Peet RK, Schildhauer M, Thiers BM (2016) Cyberinfrastructure for an integrated botanical information network to investigate the ecological impacts of global climate change on plant biodiversity. PeerJ Preprints 4:e2615v2. https:// doi.org/10.7287/peerj.preprints.2615v2

Forrester DI, Tachauer IHH, Annighoefer P, Barbeito I, Pretzsch H, Ruiz-Peinado R, Stark H, Vacchiano G, Zlatanov T, Chakraborty T, Saha S, Sileshi GW et al (2017) Generalized biomass and leaf area allometric equations for European tree species incorporating stand structure, tree age and climate. For Ecol Manage 396:160 175. https://doi.org/10.1016/j.foreco.2017.04.011

Gazda A, Szwagrzyk J (2016) Introduced species in Polish National Parks: distribution, abundance and management approaches. In: Krumm F, Vítková L (eds) Introduced tree species in European forests: opportunities and challenges. European Forest Institute, Freiburg, pp 168-175

GBIF (2019) Global Biodiversity Information Facility. http://www. gbif.org/

Gentili R, Ferrè C, Cardarelli E, Montagnani C, Bogliani G, Citterio S, Comolli R et al (2019) Comparing negative impacts of Prunus serotina, Quercus rubra and Robinia pseudoacacia on native forest ecosystems. Forest 10:842. https://doi.org/10.3390/f10100842

Hartig F (2020) DHARMa: Residual Diagnostics for Hierarchical (Multi-Level / Mixed) Regression Models. R package version 0.2.7. https://cran.r-project.org/package=DHARMa

Hartman KM, McCarthy BC (2007) A dendro-ecological study of forest overstorey productivity following the invasion of the nonindigenous shrub Lonicera maackii. Appl Veg Sci 10:3-14. https:// doi.org/10.1111/j.1654-109X.2007.tb00498.x

Heinrichs S, Schmidt W (2009) Short-term effects of selection and clear cutting on the shrub and herb layer vegetation during the conversion of even-aged Norway spruce stands into mixed stands. For Ecol Manage 258:667-678. https://doi.org/10.1016/j.foreco.2009.04.037

Hejda M, Hanzelka J, Kadlec T, Štrobl M, Pyšek P, Reif J et al (2017) Impacts of an invasive tree across trophic levels: Species richness, community composition and resident species' traits. Divers Distrib 23:997-1007. https://doi.org/10.1111/ddi.12596

Horodecki P, Jagodziński AM (2017) Tree species effects on litter decomposition in pure stands on afforested post-mining sites. For Ecol Manage 406:1-11. https://doi.org/10.1016/j.foreco.2017.09.059

Jagodziński AM, Dyderski MK, Horodecki P, Knight KS, Rawlik K, Szmyt J et al (2019) Light and propagule pressure affect invasion intensity of Prunus serotina in a 14-tree species forest common garden experiment. NeoBiota 46:1-21. https://doi.org/10.3897/ neobiota.46.30413

Jagodziński AM, Dyderski MK, Horodecki P, Rawlik K (2018) Limited dispersal prevents Quercus rubra invasion in a 14-species common garden experiment. Divers Distrib 24:403-414. https:// doi.org/10.1111/ddi.12691

Jin Y, Qian H (2019) V.PhyloMaker: an R package that can generate very large phylogenies for vascular plants. Ecography 42:13531359. https://doi.org/10.1111/ecog.04434

Karolewski P, Giertych MJ, Żmuda M, Jagodziński AM, Oleksyn J (2013) Season and light affect constitutive defenses of understory shrub species against folivorous insects. Acta Oecologica 53:1932. https://doi.org/10.1016/j.actao.2013.08.004

Karolewski P, Łukowski A, Adamczyk D, Żmuda M, Giertych MJ, Mąderek E et al (2020) Species composition of arthropods on six understory plant species growing in high and low light conditions. Dendrobiol 84:58-80. https://doi.org/10.12657/denbio.084.006

Kleyer M, Bekker RM, Knevel IC, Bakker JP, Thompson K, Sonnenschein M, Poschlod P, Van Groenendael JM, Klimeš L, Klimešová J, Klotz S, Rusch GM, Hermy M, Adriaens D, Boedelthje G, Bossuyt B, Dannemann A, Endels P, Götzenberger L, Hodgson JG, Jackel A-K, Kühn I, Kunzmann D, Ozinga WA, Römermann C, Stadler M, Schlegelmilch M, Steendam HJ, Teckenberg O, Wilmann B, Cornelissen JH, Eriksson O, Garnier E, Peco B et al (2008) The LEDA Traitbase: a database 
of life-history traits of the Northwest European flora. J Ecol 96:1266-1274. https://doi.org/10.1111/j.1365-2745.2008.01430.x

Klotz S, Kühn I, Durka W (2002) BIOLFLOR - Eine Datenbank zu biologisch-ökologischen Merkmalen der Gefäßpflanzen in Deutschland. Schriftenreihe für Vegetationskunde, Bundesamt für Naturschutz, Bonn

Laliberté E, Legendre P (2010) A distance-based framework for measuring functional diversity from multiple traits. Ecol 91:299 305. https://doi.org/10.1890/08-2244.1

Laliberté E, Legendre P, Shipley B (2014) FD: Measuring functional diversity (FD) from multiple traits, and other tools for functional ecology. https://cran.r-project.org/package $=$ FD

Lenth R (2019) emmeans: Estimated Marginal Means, aka LeastSquares Means. https://cran.r-project.org/package=emmeans

Marozas V, Straigyte L, Sepetiene J (2009) Comparative analysis of alien red oak (Quercus rubra L.) and native common oak (Quercus robur L.) vegetation in Lithuania. Acta Biologica Universitatis Daugavpiliensis 9:19-24

Mason NWH, Mouillot D, Lee WG, Wilson JB (2005) Functional richness, functional evenness and functional divergence: the primary components of functional diversity. Oikos 111:112-118. https://doi.org/10.1111/j.0030-1299.2005.13886.x

Mikulová K, Jarolímek I, Bacigál T, Hegedüšová K, Májeková J, Medvecká J, Slabejová D, Šibík J, Škodová I, Zaliberová M, Šibíková $\mathrm{M}$ et al (2019) The effect of non-native black pine (Pinus nigra J. F. Arnold) plantations on environmental conditions and undergrowth diversity. For 10:548. https://doi.org/10.3390/f10070548

Nakagawa S, Schielzeth H (2013) A general and simple method for obtaining R2 from generalized linear mixed-effects models. Methods Ecol Evol 4:133-142. https://doi.org/10.1111/j.2041210x.2012.00261.x

Oksanen J, Blanchet FG, Kindt R, Legendre P, Michin PR, O'Hara RB, Simpson GL, Solymos P, Henry M, Stevens H, Wagner $\mathrm{H}$ et al (2018) "vegan" 2.3.3. - Community Ecology Package. https://cran.rproject.org/package $=$ vegan

Orzeł S (2015) Skład gatunkowy i biomasa nadziemna krzewów w podszycie drzewostanów Puszczy Niepołomickiej. Sylwan 159:848-856

Ostrom AJ (1983) Tree and shrub biomass estimates for Michigan, 1980. Research Note NC-302. USDA Forest Service, North Central Forest Experiment Station, St. Paul, Minnesota

Penone C, Davidson AD, Shoemaker KT, Di Marco M, Rondinini C, Brooks TM, Young BE, Graham CH, Costa GC et al (2014) Imputation of missing data in life-history trait datasets: which approach performs the best? Methods Ecol Evol 5:961-970. https:// doi.org/10.1111/2041-210X.12232

Pyšek P, Manceur AM, Alba C, McGregor KF, Pergl J, Štajerová K, Chytrý M, Danihelka J, Kartesz J, Klimešová J, Lučanová M, Moravcová L, Nishino M, Sádlo J, Suda J, Tichý L, Kühn I et al (2015) Naturalization of central European plants in North America: species traits, habitats, propagule pressure, residence time. Ecol 96:762-774. https://doi.org/10.1890/14-1005.1

R Core Team (2019) R: a language and environment for statistical computing. R Foundation for Statistical Computing, Vienna, Austria

Rice SK, Westerman B, Federici R (2004) Impacts of the exotic, nitrogen-fixing black locust (Robinia pseudoacacia) on nitrogen-cycling in a pine-oak ecosystem. Plant Ecol 174:97-107. https://doi.org/10.1023/B:VEGE.0000046049.21900.5a

Santos T (2018) PVR: Phylogenetic eigenvectors regression and phylogentic signal-representation curve

Sapsford SJ, Brandt AJ, Davis KT, Peralta G, Dickie IA, Gibson RD, Green JL, Hulme PE, Nuñez MA, Orwin KH, Pauchard A, Wardle DA, Peltzer DA et al (2020) Towards a framework for understanding the context-dependence of impacts of non-native tree species. Funct Ecol 34:944-955. https://doi.org/10.1111/1365-2435.13544

Šibíková M, Jarolímek I, Hegedüšová K, Májeková J, Mikulová K, Slabejová D, Škodová I, Zaliberová M, Medvecká J et al (2019) Effect of planting alien Robinia pseudoacacia trees on homogenization of Central European forest vegetation. Sci Total Environ 687:1164-1175. https://doi.org/10.1016/j.scitotenv. 2019.06.043

Škèma M, Mikšys V, Aleinikovas M, Kulbokas G, Urbaitis G (2015) Underbrush biomass in Lithuanian forests: factors affecting quantities. Baltic For 21:124-132

Slabejová D, Bacigál T, Hegedüšová K, Májeková J, Medvecká J, Mikulová K, Šibíková M, Škodová I, Zaliberová M, Jarolímek I et al (2019) Comparison of the understory vegetation of native forests and adjacent Robinia pseudoacacia plantations in the Carpathian-Pannonian region. For Ecol Manage 439:28-40. https://doi.org/10.1016/j.foreco.2019.02.039

Stekhoven DJ, Bühlmann P (2012) MissForest-non-parametric missing value imputation for mixed-type data. Bioinform 28:112118. https://doi.org/10.1093/bioinformatics/btr597

Terwei A, Zerbe S, Mölder I, Annighöfer P, Kawaletz H, Ammer $\mathrm{C}$ et al (2016) Response of floodplain understorey species to environmental gradients and tree invasion: a functional trait perspective. Biol Invasions 18:2951-2973. https://doi.org/10.1007/ s10530-016-1188-0

Tsirogiannis C, Sandel B (2016) PhyloMeasures: a package for computing phylogenetic biodiversity measures and their statistical moments. Ecography 39:709-714. https://doi.org/10.1111/ecog.01814

Wasserstein RL, Lazar NA (2016) The ASA's Statement on p-values: context, process, and purpose. Am Stat 70:129-133. https://doi. org/10.1080/00031305.2016.1154108

Wild J, Kaplan Z, Danihelka J, Petřík P, Chytrý M, Novotný P, Rohn M, Šulc V, Brůna J, Chobot K, Ekrt L, Holubová D, Knollová I, Kocián P, Štech M, Štěpánek J, Zouhar V et al (2019) Plant distribution data for the Czech Republic integrated in the Pladias database. Preslia 91:1-24. https://doi.org/10.23855/preslia.2019.001

Woodbury PB, Smith JE, Heath LS (2007) Carbon sequestration in the U.S. forest sector from 1990 to 2010. For Ecol Manage 241:14 27. https://doi.org/10.1016/j.foreco.2006.12.008

Woziwoda B, Dyderski MK, Jagodziński AM (2019) Effects of land use change and Quercus rubra introduction on Vaccinium myrtillus performance in Pinus sylvestris forests. For Ecol Manage 440:1-11. https://doi.org/10.1016/j.foreco.2019.03.010

Zerbe S, Wirth P (2006) Non-indigenous plant species and their ecological range in Central European pine (Pinus sylvestris L.) forests. Ann For Sci 63:189-203. https://doi.org/10.1051/forest:2005111 